\title{
EFFECT OF GnRH TREATMENT DURING DIFFERENT TIMES POST-MATING ON PREGNANCY RATE OF BUFFALO HEIFERS
}

\author{
Abo-Farw, M.A. ${ }^{1}$, I.T. El-Ratel ${ }^{1}$, A.E. Abdel-Khalek ${ }^{2}$, H.A.Abouelghet ${ }^{1}$ and M.M. Ghoneim ${ }^{1}$ \\ 1- Animal Production Research Institute, Agricultural Research Center, Giza, Egypt, 2- Department of \\ Animal Production, Faculty of Agriculture, Mansoura University, Mansoura, Egypt
}

\section{SUMMARY}

To evaluate the efficiency of GnRH injection, on day of mating (Day 0 ) or during different days post-mating (Day 10 or Day 12), on conception rate of repeat breeder buffalo heifers, a total of 20 cyclic Egyptian buffalo heifers (2-4 years of age and 350-400 kg LBW was allotted to four experimental groups. All heifers had mature $C L s$ and were injected i.m. with $2.5 \mathrm{ml} P G F 2 \alpha$ analogue (Estrumate)/h. Heifers in heat were naturally mated by fertile buffalo bull and allotted randomly to four experimental groups, 5 animals in each. On day of estrus, heifers were injected with $2.5 \mathrm{ml}$ saline (G1, control), or a single dose of $2.5 \mathrm{ml}$ Receptal on days 0,10 and 12 post-mating in G2, G3 and G4, respectively. Blood samples were collected for determination of P4 concentration in blood serum. Pregnancy was diagnosed on day 25 post-mating of each animal using ultrasound examination. Results showed that conception rate $(C R)$ was the highest $(P<0.05)$ in G3 and G4 $(80 \%)$, moderate in $G 2(60 \%)$ and the lowest in $G 1(40 \%)$. Serum P4 concentration was the highest $(P<0.05)$ in G4 on most sampling days. There were insignificant differences in serum P4 on day of estrus, being $\leq 0.5 \mathrm{ng} / \mathrm{ml}$ in all groups. Concentration of P4 was the highest $(P<0.05)$ in $G 2$ as compared to other groups. Heifers in G4 showed the highest response to GnRH injection on day 12, whereas P4 concentration tended to increase on day of GnRH injection. There were marked group differences in P4 concentration on days 22 and 24, but P4 concentration was always $\geq 2 \mathrm{ng} / \mathrm{ml}$ in all groups. Level of $P 4$ was higher $(P<0.05)$ in pregnant than in nonpregnant heifers within each group.

In conclusion, GnRH administration $(2.5 \mathrm{ml}$ Receptal/h) on day 12 of estrus/mating had positive effect on pregnancy rate of repeat breeder buffalo heifers as compared to those injected on day 0 and 10 of mating.

\section{Keywords: buffaloes, repeat breeder, GnRH, conception rate, progesterone}

\section{INTRODUCTION}

The success of dairy industry is dependent on the milk production of dairy cattle and buffaloes (Bajaj et al., 2006).Milk production is directly related to the reproductive phenomenon. Mortality is more common during the early embryonic period (from day $8^{\text {th }}$ to $\left.16^{\text {th }}\right)$ without an effect on estrous cycle length (Bajaj and Neelesh, 2011)and it is one of the major causes for repeat breeding in dairy cows (Santoset al., 2004 and Diskin and Morris, 2008), leading to declined fertility in buffaloes.Embryonic mortality (EM) may be, partially, attributed to a decrease in progesterone $\left(\mathrm{P}_{4}\right)$ secretion by the corpus luteum (CL) during early pregnancy (Campanile et al., 2005). EM appears to occur on day 25-40 in buffalo (Campanile et al., 2005) later than on day 1417 in cows (Mann, 2002).

The GnRH was suggested to have luteotropic and luteoprotective factors, thereby enabling maternal recognition of pregnancy (Macmillan et al., 1986). Abnormal CL function is associated with reduced pregnancy rates (Hommeidaa et al., 2004). Measurement of blood $\mathrm{P}_{4}$ suggested that embryonic death at the time of $\mathrm{CL}$ maintenance delayed luteolysis and interestrus interval (Humblot, 2001). $\mathrm{GnRH}$ treatment may increase the chances of embryo survival by improving luteal function and/or interfering with the luteolytic mechanism (Beck et al., 1994; Birnie et al., 1997 and ; Cam et al., 2002).
Several hormonal treatments have been attempted to reduce embryonic loss or improve pregnancy rates in cattle, including the use of gonadotrophin releasing hormone $(\mathrm{GnRH})$ and human chorionic gonadotropin (HCG), but their effects on pregnancy rates and plasma $\mathrm{P} 4$ profile are inconsistent(Yildiz et al., 2009).

In lactating dairy cows, injection of GnRH agonist (buserelin) between the $11^{\text {th }}$ and $13^{\text {th }}$ day postmating resulted in extended inter-estrous interval and elevated level of $\mathrm{P}+$ in blood serum (Stevenson et al., 1993). GnRH-induced biological affects the reproductive-endocrine system to increase conception rates. This effect may induce through GnRHstimulated LH surge and stimulating $\mathrm{P}_{4}$ production by CL (Gaja et al., 2008).In buffalo, treatment with GnRH agonist on day 5 after AI induced ovulation rate of $62 \%$ and increased milk whey $\mathrm{P} 4$ in response to gonadotrophin (Campanile et al., 2007a). Buserelin or hCG treatment increased $\mathrm{P}_{4}$ level but did not reduce the EM, with injection on day 5 after AI (Campanile et al., 2007b) and increased $\mathrm{P}_{4}$ level and reduced EM in Mediterranean buffaloes with administration on 25 days after AI (Campanile et al., 2007c).

The objective of the this study was to evaluate the potentiality of GnRH injection, on day of mating ( 0 day) or during different days post-mating (Day 10 or 12), on pregnancy rate of repeat breeder buffalo heifers. 


\section{MATERIALS AND METHODS}

The study was conducted at Animal Production Experimental Station, Mehallet Moussa, Kaferelsheikh Governorate, Animal Production Research Institute, Agricultural Research Center, Ministry of Agriculture during the period from April 2014 to June 2015.

\section{Animals:}

A total of 20 cyclic Egyptian buffalo heifers, 2 to 4 years of age and 350-400 kg live body weight was used in this study. The cyclicity of heifers was proved by mating these heifers more than three times with returning to estrus. All heifers used in this study showed previously normal estrous cycle and had no clinically illness signs detectable. The examination of reproductive tract of all heifers by rectal palpation and ultrasonography revealed that the genital tract of all animals were free from any pathological diseases and disorders. All heifers failed to conceive after more than 3 services per animal to be considered as repeat breeder buffalo heifers. All animals had mature CLs at the beginning of the experimental period.

The experimental animals were allotted to four experimental groups according to the hormonal treatment (5 animals in each). Through the experimental period, all experimental animals were kept under the regular systems of feeding and management adopted by Animal Production Research Institute. Fresh water was available all times. Buffalo heifers were housed in semi-open sheds.

\section{Experimental design:}

The experimental heifers in all groups had mature CL sand were injected intramuscularly with 2.5 $\mathrm{ml} /$ animal of PGF2 $\alpha$ analogue (Estrumate, Essex Animal Health Fresoythe Sedelsberger Strasse 2-4. 26169 Friesoythe, Germany) containing $0.625 \mu \mathrm{g} / \mathrm{ml}$ Cloprostenol sodium to synchronize the estrous cycle. At the end of treatment, estrus was detected for $72 \mathrm{~h}$ at every morning and evening by close observation for external signs in presence of a teaser buffalo bull all the times of observation.

Heifers in heat were naturally inseminated by fertile buffalo bull and allotted randomly to four experimental groups (5 animals in each). Heifers in the $1^{\text {st }}$ group (G1) were injected with $2.5 \mathrm{ml}$ saline at the time of mating and were considered as control group. However, heifers in the $2^{\text {nd, }} 3^{\text {rd }}$ and $4^{\text {th }}$ groups were injected intramuscularly with a single dose of $2.5 \mathrm{ml} \mathrm{GnRH}$ analogue (Receptal, Product of Intervet International GmbH. Germany Imported by Intervet Egypt. Reg N 2139) on day 0 (G2), 10 (G3) and 12 (G4) from estrus onset, respectively.Each $\mathrm{ml}$ Receptal contained $4 \mu \mathrm{g}$ Buserelin acetate.

\section{Blood samples:}

Blood samples were collected by jugular venipuncture from all animals of each group on days0, 2, 4, 6, 8, 10, 12, 14, 16, 18, 20, 22 and 24 of mating. Blood samples were collected in sterilized glass tubes and kept at room temperature. Within an hour after collection, samples were centrifuged at $3000 \mathrm{rpm}$ for $15 \mathrm{~min}$ and transferred into sterilized serum vials. All samples were stored at $-20{ }^{\circ} \mathrm{C}$ to for determination of progesterone $\left(\mathrm{P}_{4}\right)$ concentration in blood serum.

\section{Hormone assay:}

Direct Radioimmunoassay technique (RIA) was performed for determination of serum $\mathrm{P}_{4}$ concentration using ready antibody coated tubes kit (Diagnosis Systems Laboratories Texas, USA) according to the procedure outlined by the manufacturer.

\section{Pregnancy diagnosis:}

Pregnancy was diagnosed on day 25 post-mating of each animal using ultrasound examination (Digital ultrasonic diagnostic imaging System, Model Dp-30 Vet. 50/60 HZ, SHENZHEN, MINDRAY BIOMEDICAL.ELECTRONICS, CO. LTD) $7.5 \mathrm{MHz}$ Linear array transducer and Depth 4.3. Pregnancy was indicated by in non-returned animal by rectal palpation on day 45-50 post-mating. Then conception rate was calculated.

\section{Statistical analysis:}

Statistical analysis for the obtained data were performed using general linear model of SAS (2000) while differences among the treatment means were performed using Duncan's Multiple Range Test (Duncan, 1955).

\section{RESULTS AND DISCUSSION}

\section{Conception rate:}

Data in table (1) showed that the conception rate (CR) was significantly $(\mathrm{P}<0.05)$ the highest in $\mathrm{G} 3$ and G4 (80\%), moderate in G2 $(60 \%)$ and the lowest in G1 (40\%). This means that GnRH injections on day 10 or 12 of estrus were more effective on improving $\mathrm{CR}$ as compared to that injected on day 0 , which significantly $(\mathrm{P}<0.05)$ increased $\mathrm{CR}$ as compared to that of control group (G1). Such results indicated that GnRH administration on 0,10 and 12 days of estrus had significant $(\mathrm{P}<0.05)$ impact on $\mathrm{CR}$ of buffalo heifers.

In accordance with the present results, Karimi et al. (2007) showed 10\% improvement in CR (70 vs. $80 \%$ ) when GnRH was administered to dairy heifers on day of estrus. Attoo et al. (2013) found that the GnRH agonist administration improved $\mathrm{CR}$ in buffaloes when administered on day 13 post-breeding $(80 \%)$ compared to day $0(70 \%)$ or day $11(70 \%)$. Mandal et al. (2009) reported an improvement in CR (75.0 vs. 87.5\%) of buffaloes treated with GnRH on day of estrus as compared to control. However, in cattle, Iftikhar et al. (2009) also observed improvement in CR (37.5 vs. 68.75\%) when GnRH was injected at the time of insemination. Rangnekar et al. (2002) reported CR of $70 \%$ in repeat breeder Holstein-Friesian cows. 
Table 1. Conception rate (\%) of buffalo heifers in the experimental groups

\begin{tabular}{lcccc}
\hline $\begin{array}{c}\text { Experimental } \\
\text { group }\end{array}$ & $\begin{array}{c}\text { Number of } \\
\text { animals }\end{array}$ & Pregnant & Non pregnant & Conception rate \\
\cline { 3 - 4 }$(\boldsymbol{\%})$
\end{tabular}

a, b and c: Means denoted within the same column with different superscripts are significantly different at $\mathrm{P}<0.05$.

Failure of ovulation might be prevented and CR might increase by GnRH administered at AI. The improvement in CR of buffalo heifers treated with GnRH on day of estrus observed in our study may possibly be related to better synchrony of preovulatory LH surge and ovulation (Tanabe et al., 1994), due to its beneficial effect on embryo survival by enhancing luteal function (Attoo et al., 2013), or by stimulating the transformation of follicular cells to luteal cells, which was required at least 2 to 3 days for optimum P4 production (Stevenson et al., 1993). $\mathrm{GnRH}$ at estrus may potentiate conversion of small luteal cells to large luteal cells resulting into development of large sized functional CL required for embryo survival through enhanced $\mathrm{P} 4$ secretion (Attoo et al., 2013).On the other hand, Perry and Perry (2009) found that the GnRH administration failed to exhibit a positive impact on pregnancy rate. A reason for non-impact on fertility could be due to GnRH-induced ovulation of physiologically immature follicles that had a negative impact on pregnancy rates and lead to late embryonic/fetal survival (Busch et al., 2008; Lynch et al., 2010).

\section{Progesterone profile:}

Results presented in table (2) indicated significant $(\mathrm{P}<0.05)$ differences in serum $\mathrm{P}_{4}$ concentration among the experimental groups on most sampling days. Serum $\mathrm{P}_{4}$ concentration was significantly $(\mathrm{P}<0.05)$ the highest in $\mathrm{G} 4$ on most sampling days. Results also showed insignificant differences in serum $\mathrm{P}_{4}$ on day of estrus, being $\leq 0.5 \mathrm{ng} / \mathrm{ml}$ in all groups, and indicating incidence of estrus and ovulation as well as complete regression of all CLs presented at the beginning of treatment in all heifers used in this study. It is well known that all animals used in this study were treated with PGF2 $\alpha$ to induce estrus/ovulation of treated heifers. Many authors reported similar findings on Egyptian buffalo cows (El-Moghazy et al., 2006) and buffalo heifers (Aboul-Ela et al., 2006).

It is of interest to note that $\mathrm{P} 4$ concentration was the highest in G2 as compared to other groups, showing response of animals in these groups to $\mathrm{GnRH}$ injection on day of estrus. However, the increase in P4 concentration in G3 compared with G1 (control) was observed staring on day 14 up to day 24. Such finding revealed lower response of animals in this group to GnRH following GnRH injection on day 10. However, heifers in G4 showed the highest response to GnRH injection on day 12, whereas P4 concentration tended to increase on day of GnRH injection.

The present results are in agreement with Attoo $e t$ al. (2013), who showed significant differences $(\mathrm{P}<0.05)$ in serum $\mathrm{P} 4$ levels in buffaloes treated with GnRH on day $5(1.78 \mathrm{ng} / \mathrm{ml})$, day $13(4.51 \mathrm{ng} / \mathrm{ml})$, and day $18(6.55 \mathrm{ng} / \mathrm{ml})$ in comparison with control group on the same days $(1.39,3.77$ and $5.11 \mathrm{ng} / \mathrm{ml}$, respectively).Also, the increase in $\mathrm{P} 4$ concentration as affected by GnRH injection was noted in dairy heifers (Karimi et al., 2007)or in buffaloes (Mandal et al., 2009).

Table 2. Progesterone $\left(\mathbf{P}_{4}\right)$ concentration $(\mathrm{ng} / \mathrm{ml})$ in blood serum of buffalo heifers in the experimental groups

\begin{tabular}{ccccc}
\hline \multirow{2}{*}{ Day post-mating } & \multirow{2}{*}{ G1 (Control) } & \multicolumn{3}{c}{ GnRH treatment } \\
\cline { 3 - 5 } & $0.481 \pm 0.04$ & $0.453 \pm 0.0$ & $0.422 \pm 0.03$ & $0.410 \pm 0.03$ \\
2 & $0.790 \pm 0.10^{\mathrm{c}}$ & $1.59 \pm 0.14^{\mathrm{a}}$ & $1.194 \pm 0.10^{\mathrm{b}}$ & $0.692 \pm 0.05^{\mathrm{c}}$ \\
4 & $1.20 \pm 0.05^{\mathrm{b}}$ & $1.82 \pm 0.23^{\mathrm{ab}}$ & $1.330 \pm 0.08^{\mathrm{b}}$ & $2.024 \pm 0.26^{\mathrm{a}}$ \\
6 & $2.98 \pm 0.09$ & $2.91 \pm 0.19$ & $2.782 \pm 0.23$ & $3.502 \pm 0.40$ \\
8 & $3.30 \pm 0.37^{\mathrm{b}}$ & $3.77 \pm 0.19^{\mathrm{ab}}$ & $3.752 \pm 0.23^{\mathrm{ab}}$ & $4.590 \pm 0.42^{\mathrm{a}}$ \\
10 & $3.40 \pm 0.17$ & $3.91 \pm 0.16$ & $3.724 \pm 0.24$ & $3.766 \pm 0.28$ \\
12 & $3.27 \pm 0.32^{\mathrm{b}}$ & $3.79 \pm 0.28^{\mathrm{ab}}$ & $4.110 \pm 0.05^{\mathrm{ab}}$ & $4.636 \pm 0.33^{\mathrm{a}}$ \\
14 & $4.24 \pm 0.22^{\mathrm{b}}$ & $4.32 \pm 0.20^{\mathrm{b}}$ & $4.974 \pm 0.22^{\mathrm{a}}$ & $5.436 \pm 0.17^{\mathrm{a}}$ \\
16 & $4.39 \pm 0.27^{\mathrm{b}}$ & $4.95 \pm 0.29^{\mathrm{b}}$ & $5.036 \pm 0.33^{\mathrm{ab}}$ & $6.006 \pm 0.38^{\mathrm{a}}$ \\
18 & $3.92 \pm 0.63^{\mathrm{b}}$ & $4.64 \pm 0.22^{\mathrm{ab}}$ & $5.564 \pm 0.38^{\mathrm{a}}$ & $5.582 \pm 0.23^{\mathrm{a}}$ \\
20 & $2.49 \pm 0.93$ & $4.29 \pm 0.92$ & $5.102 \pm 0.67$ & $5.048 \pm 0.65$ \\
22 & $2.70 \pm 0.29^{\mathrm{c}}$ & $3.62 \pm 0.21^{\mathrm{bc}}$ & $4.294 \pm 0.25^{\mathrm{ab}}$ & $5.122 \pm 0.32^{\mathrm{a}}$ \\
24 & $2.18 \pm 0.90^{\mathrm{c}}$ & $3.02 \pm 1.05^{\mathrm{bc}}$ & $4.308 \pm 0.96^{\mathrm{ab}}$ & $4.644 \pm 1.11^{\mathrm{a}}$ \\
\hline
\end{tabular}


In addition, the present results indicated marked group differences in P4 concentration on days 22 and 24 , but $\mathrm{P} 4$ concentration was always $\geq 2 \mathrm{ng} / \mathrm{ml}$ in all groups. This may indicate incidence of pregnancy with different trends among groups. It is worth noting that P4 level was in accordance with CR (number of pregnant animals) in each group (Table 1), being significantly $(\mathrm{P}<0.05)$ the highest in G4 and G3, followed by G2 and the lowest in G1 (Table 2).

Concerning the overall concentration of $\mathrm{P}_{4}$ in pregnant and non-pregnant heifers in each group
(Fig. 1), the statistical analysis revealed that P4 level was significantly $(\mathrm{P}<0.05)$ higher in pregnant than in non-pregnant heifers. Cows were regarded to be pregnant when the $\mathrm{P}_{4}$ concentration in serum was $\geq 1.6 \mathrm{ng} / \mathrm{ml}$ on day 24 post-mating (Yildiz et al., 2009). The later author found that pregnancy rate in cows treated with GnRH was $77.7 \%$ compared with $50 \%$ in control group. Also, some authors (Tefera et al., 2001; Howard et al., 2006) showed that injection of GnRH on days 11 to 14 after AI in lactating cows increased serum $\mathrm{P}_{4}$ level.

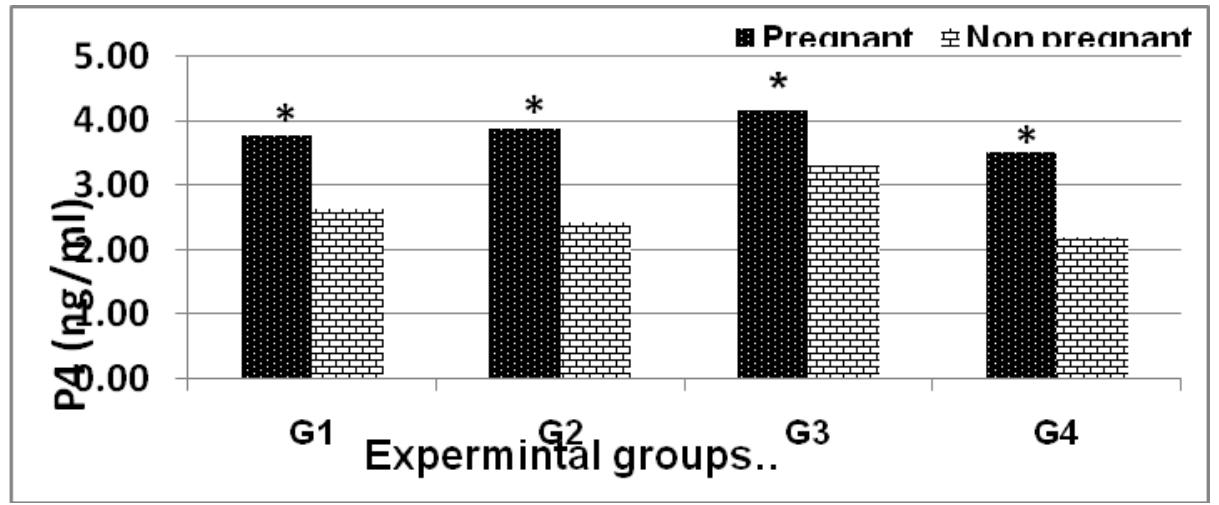

Fig. 1. Progesterone (P4) concentration (ng/ml) in pregnant and non-pregnant buffalo heifers of the experimental groups

As a result of $\mathrm{GnRH}$ administration at estrus induces, Aboul-Ela et al. (1985) suggested release of both LH and FSH in buffaloes which causes maturation of ovarian follicles and ovulation. This might also act by enhancing or altering theca lutein cells in the preovulatory and postovulatory follicles or on developing CL to promote conversion of small lutein cells into large lutein cells, resulting into development of large sized functional CL, enhancing P4 secretion required for embryo survival. Also, Campanile et al. (2007) found that the GnRH treatment may be utilized in order to induce the formation of an accessory CL and hence, to increase P4 levels, which are critical for maintaining the pregnancy

\section{CONCLUSION}

Based on the foregoing results, the current study indicated that GnRH analogue (Receptal) administration at a level of $2.5 \mathrm{ml} /$ animal on day 12 post-mating improves pregnancy rate of repeat breeder buffalo heifers in comparison with day 0 or day 10 in term of positive effects on enhancing luteal function by elevating progesterone level. Further studies are required to evaluate different days during different days post-mating of repeat breeder heifers.

\section{REFERENCES}

Aboul-Ela, H.B.; Sh. A. Gabr, M.A. Abdel-Latif, and A.E. Abdel-Khalek, 2006. Reproductive performance of Egyptian buffalo heifers fed diets supplemented with yeast culture (Gastur nature):2-live body weight and ages at puberty, first service and conception. J. Agric. Mansoura Univ., 31(6):3375-3387.

Aboul-Ela, M.B., F.E. El-Keraby and R. Khattab, 1985. Effect of GnRH treatment on post-partum resumption of estrus and ovulation in buffaloes. Buffalo J. 1, 61-69.

Attoo, M.Z.; L, S. Prasad, H.P. Gupta and A. Hussain, 2013. Effect of Post-Mating GnRH Treatment on Serum Progesterone Profile and Conception Rate in Buffaloes. Iranian Journal of Applied Animal Science, 3 (1), 83-90.

Bajaj, N.K. and Sh. Neelesh, 2011. Endocrine causes of early embryonic death . An overview. Curr. Res. Dairy Sci,3(1):1-24.

Bajaj, N.K.; S. Nanavati and K. Janakiraman, 2006. Livestock training manual. M. Phill. Thesis, Gramin Vikas Trust, India.

Beck N.F.G.; A.R. Peters and S.P. Williams, 1994. The effect of the GnRH analogue (buserelin) on day 12 post mating on re-productive performance of ewes. Anim. Prod. 58, 243-247.

Birnie L.M., P.J. Broadbent and J.S.M. Hutchinson, 1997. Failure of prostaglandin $\mathrm{F} 2 \alpha$ to induce luteolysis in GnRH agonist treated heifers. Vet. Rec. 140, 315-322.

Busch, D.C.; J.A. Atkins, J.F. Bader, D.J. Schafer, D.J. Patterson, T. Geary and M.F. Wand Smith, 2008. Effect of ovulatory follicle size and expression of estrus on progesterone secretion in beef cows. J. Anim. Sci. 86, 553-563. 
Cam, M.K.; M. Kuran, S. Yildiz and E. Selcuk, 2002. Fetal growth and reproductive performance in ewes administered GnRH agonist on day 12 post mating. Anim. Reprod. Sci. 72, 73-82.

Campanile, G., D. Vecchio, M. Rendina, C. Grassi, A. Balestrieri, R. Di Palo and L. Zicarelli, 2007. Ovary response and embryonic mortality in buffaloes treated with GnRH or hCG. Ital.J.Anim.Sci. vol. 6, (Suppl. 2): 673-676.

Campanile, G.; R. Di Palo, G. Neglia, D. Vecchio, B. Gasparrini, A. Prandi, G. Galiero and M.J. D'Occhio, 2007a. Corpus luteum function and embryonic mortality in buffaloes treated with a GnRH agonist, hCG and progesterone. Theriogenology, 67: 1393-1398.

Campanile, G.; D. Vecchio, L. Zicarelli, G. Neglia, R. Di Palo, A. Balestrieri and M.J. D’Occhio, 2007b . Strategies to reduce embryonic mortality in buffalo cows. Proc. VIII Buffalo Congress.

Campanile, G.; D.Vecchio, M. Rendina, Grassi, C., A. Balestrieri and R. Di Palo, 2007c. Ovary response and embryonic mortality in buffaloes treated with GnRH or hCG. Proc. VIII Buffalo Congress.

Campanile, G.; G. Neglia, B. Gasparrini, G. Galiero, A. Prandi, R. Di Palo, M.J. D'Occhio, and L. Zicarelli, 2005 . Embryonic mortality in buffaloes synchronized and mated by AI during the seasonal decline in reproductive function. Theriogenology, 63: 2334-2340.

Diskin M.G. and D.G. Morris, 2008. Embryonic and early foetal losses in cattle and other ruminants. Reprod. Domest. Anim. 43: 260-267.

Duncan, D.B., 1955. Multiple range and Multiple F test. Biometrics, 11:10.

El-Moghazy, M.M.; M.A. El-Harairy, A.E. Abdelkelek, and M.B. Aboul-Ela, 2006. Postpartum ovarian activity of conceveid and non conceveid Egyptian buffaloes under field conditions.Fourth Scientific Converence, Giza, 29-30 July, 32-40.

Gaja, A. O.; K. Hamana, C. Kubota, and T. Kojima, 2008. Evaluation of the effect of a 3rd GnRH injection administered six days after the 2nd GnRH injection of Ovsynch on the reproductive performance of Japanese black cows. J. Vet. Sci., 9: 273-279.

Hommeidaa, A.; T.Akaoa, and H. Kubotab, 2004. Luteal function and conception in lacting cows and some factors in fluencing luteal function after first insemination.theriogenology,62:217-225.

Howard, J. M.; R. Manzo, J. Dalton, C. F. Frago, and Z. A. Ahmad, 2006. Conception rates and serum progesterone concentrations in dairy cattle administered gonadotropin releasing hormone 5 days after artificial insemination. Anim. Reprod. Sci., 95: 224-33.

Humblot, P., 2001. Use of pregnancy specific proteins and pro-gesterone assays to monitor pregnancy and determine the tim-ing, frequencies and sources of embryonic mortality in rumi-nants. Theriogenology. 56, 1417-1433.

Iftikhar, A.; Anjum, R.H.; Usmani, M.T.; Tunio, A. and S.H. Abro, 2009. Improvement of conception rate in crossbred cattle us-ing GnRH analogue therapy. Pak. Vet. J. 29, 93-94.

Karimi, A.; H. Karami, and M.M. Moeini, 2007. The effect of administration of different levels of GnRH on the Day 0, 5 and 12 Post-Insemination on progesterone concentration in dairy heifers. Pakistan J. Biol. Sci. 10(20), 3620-3625.

Lynch, C.O.; D.A. Kenny, S. Childs, and M.G. Diskin, 2010. The relationship between periovulatory endocrine and follicular activity on corpus luteum size, function, and subsequent embryo survival. Theriogenology. 73, 190-198.

Macmillan, K. L.; V.K. Taufa, and A. M. Day, 1986. Effect of an agonist of gonadotrophin releasing hormone in cattle, III. Pregnancy rates after a post-insemination injection during metoestrous or dioestrous. Anim. Reprod. Sci., 11: 1-10.

Mandal D.D.; S.K. Srivastava and P. Kumar, 2009. Effect of GnRH during various stages of estrous cycle on fertility and plasma progesterone in buffaloes. Indian J. Anim. Reprod. 30, 23-27.

Mann, G.E., 2002. Reproduction-mating management. In: Encyclopaedia of Dairy Sciences pp1770 - 1777. Eds JW Fuquay and PF Fox. Academic Press, San Diego, USA.

Perry, G.A. and B.L. Perry, 2009. GnRH treatment at artificial insemination in beef cattle fails to increase plasma progester-one concentrations or pregnancy rates. Theriogenology, 71: 775-779.

Rangnekar M.N.; R.L. Dhoble, A.G. Sawale, M.G. Gacche, M.V. Ingawale, and J.M. Jadhav, 2002. Effect of fertagyl, gonadotropin re-leasing hormone $(\mathrm{GnRH})$, administration on conception rate in re-peat breeding cows. The Blue Cross Book. 18, 20-21.

Santos J.E.P.; W.W. Thatcher; R.C. Chebel; R.L.A. Cerri and K.N. Galvao, 2004. The effect of embryonic death rates in cattle on the efficacy of estrus synchronization programs. Anim. Re-prod. Sci. 82, 513-535

SAS, 2000. SAS Institute Inc. SAS User's Guide, Statistics. Cary, NC.

Stevenson, J.S.; A.P. Phatak, I. Rettmer, and R.E. Stewart, 1993. Post-insemination administration of receptal: Follicular dynamics, duration of cycle, hormonal responses, and pregnancy rates. J. Dairy Sci., 76: 2536-2547.

Tanabe, T.Y.; D.R. Dearer and H.W. Hawk, 1994. Effect of go-nadotrophin releasing hormone on estrus, ovulation and ovum cleavage at the time of the post-coital test. Fertil. Steril. 55, 513-515.

Tefera, M.; S. Chaffaux, M. Thibier, and P. Humblot, 2001. A short note: lack of effect of post-AI hCG or GnRH treatment on embryonic mortalitiy in dairy cattle. Livestock Prod. Sci., 71: 277-281. 
Yildiz H.; E. Kaygusuzoglu, M. Kaya, and M. Cenesiz, 2009. Effect of post-mating GnRH treatment on serum progesterone, luteinizing hormone levels, duration of estrous cycle and pregnancy rates in cows. Pak. Vet. J. 29(3), 110114.

تأثير المعاملة بـ GnRH أثناء أوقات مختلفة بعد التلقيح على معدل الحمل فى عجلات الجاموس

محمد عبد القتاح ابو فرو'، ابراهيم طلعت الرطل'، عبد الخالق السيد عبد الخالق'، حسب الله عبد الجواد ابوالغيط'، مسعود محمد

1 ـ معهل بحوث الإنتاج الحيوانسي، مركز البحوث الزراعية، r ـ قسم الإنتاج الصيوانسي، كلية الزراعة، جامعة المنصورة

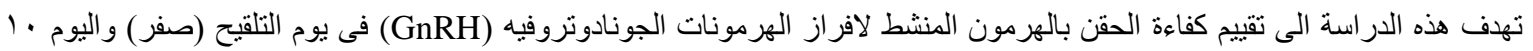

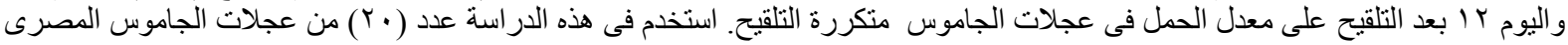

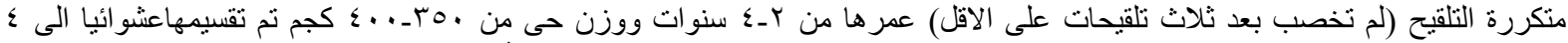

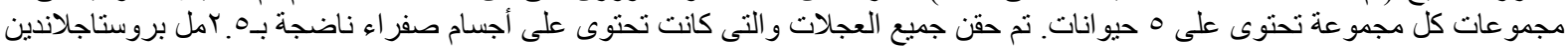

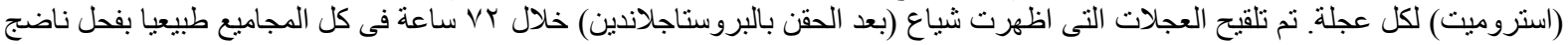

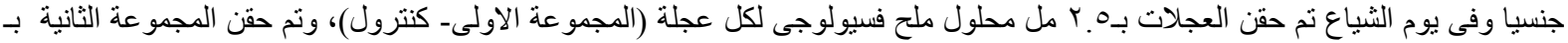

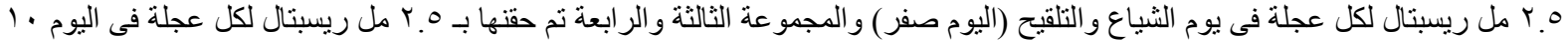

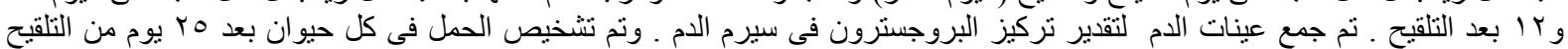

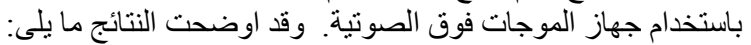

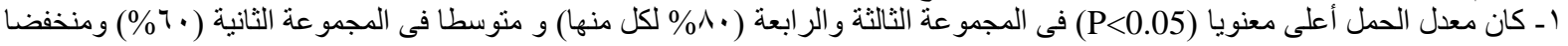

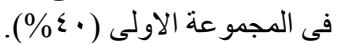

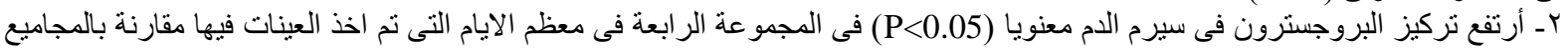
الاخرى. الاخع ترن

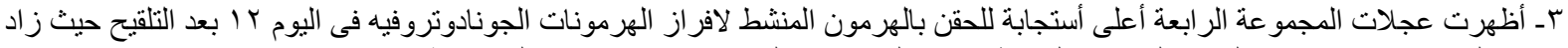

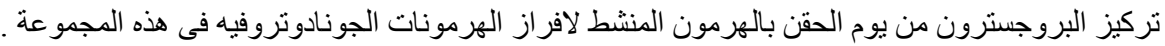

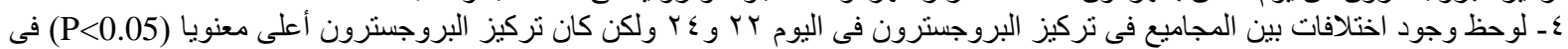

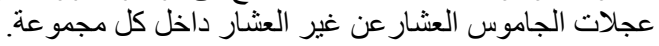

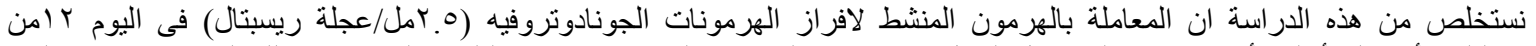

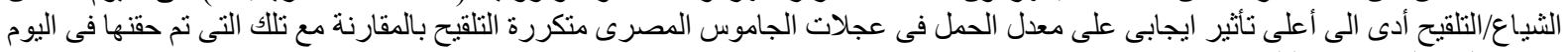

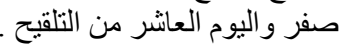

